\title{
Eco-bricks Method to Reduce Plastic Waste in Tanjung Mekar Village, Karawang Regency
}

\author{
Dwi Ariyani ${ }^{1 *}$, Niken Warastuti ${ }^{1}$, Resti Nur Arini ${ }^{1}$ \\ ${ }^{1}$ Civil Engineering Department, Faculty of Engineering, Pancasila University, South \\ Jakarta, 126400, Indonesia \\ dwi.ariyani@univpancasila.ac.id
}

Received 22-11-2020; accepted 28-12-2020

\begin{abstract}
Plastic waste is a source of environmental pollution in Indonesia. The increase in the use of plastic materials has resulted in an increase in the production of plastic waste from year to year. Destruction of plastic waste by burning will only worsen health because of the dioxin substances produced. The most appropriate method to handle waste is to use the eco-bricks method. The aim of the study was to see the strength of eco-bricks material compared to other materials usually use in the market like red bricks and concrete bricks. The test is carried out using a compressive strength testing machine on several specimens. From the results of tests in the concrete laboratory University of Pancasila using eco-bricks material, with three specimens are plastic bottles filled with pure plastic, sand, and a mixture of plastic and sand, compared to red bricks and concrete bricks in the market. The strength test results show that the eco-bricks material containing sand shows the greatest compressive strength value is $41.2 \mathrm{Mpa}$, compared to the red bricks which is $27 \mathrm{Mpa}$ and concrete bricks is $38 \mathrm{Mpa}$. From the result eco-bricks has a higher compressive strength value than other materials.
\end{abstract}

Keywords: compressive strength, eco-bricks, plastic waste, strength

\section{Introduction}

According to a survey by Nova Chemicals, Indonesia is the second largest contributor to sea waste after China, which is 1.29 million metric tons/year. At present there are still many people in Indonesia who throw garbage in any place, and can caused flooding in the river. The river is polluted with a lot of waste, one of which is the Citarum River. Citarum River is a river that is very important for residents of West Java. The condition of the Citarum River which is very alarming is polluted by waste and garbage. In the world's leading survey site, the Citarum River occupies the $4^{\text {th }}$ position for the dirtiest river problem. The rubbish that pollutes the Citarum River is more inorganic or unbiodegradable, for example plastic, bottles or beverage cups, plastic food wrapping, and so on. As we know plastic waste is very difficult to decompose, it takes more than 100 years to decompose the plastic decomposed or decompose completely [1]. Garbage is a common problem, currently all countries in the world are facing the same problem, regarding waste management, especially plastic waste, because plastic takes

Cite this as: Ariyani, D., Warastuti, N., \& Arini, R.N. (2021). Eco-bricks Method to Reduce Plastic Waste in Tanjung Mekar Village, Karawang Regency. Civil and Environmental Science Journal (Civense), 4(1), 22-29. doi: https://doi.org/10.21776/ub.civense.2021.00401.3 
decades to decompose properly, currently plastic production in the world currently reaches 300 million tons per year [2], it is estimated that there are 150 million tons of plastic in the ocean and another 250 million tons will increase the burden of marine waste towards the trend of increasing urbanization [3]. Currently, Indonesia ranks second in producing plastic waste after China, which is estimated to reach 3.22 million tons per year, even four large rivers in Indonesia are named as the top 20 dirtiest rivers in the world, namely Brantas, Solo, Progo and Serayu.

The plastic waste reduction program is currently being promoted throughout the world, the Government of Indonesia is targeting that by 2025 it can reduce plastic waste and other waste in the next sea by $70 \%$, and targets the reuse of plastic waste by $30 \%$ [4], there are many methods to achieve the target. These include reusing existing plastic waste (reuse), eco bricks is a method of reusing plastic waste as an alternative to environmentally friendly building materials, currently people are still doubtful about the use of eco bricks, especially with regard to technical properties. It is necessary to make a comprehensive research to determine the technical properties of the eco bricks. Testing of ecobricks materials using sand and plastic waste to produce bricks, was carried out by heating at 2000C. Then compared the results between bricks mixed with sand and plastic with traditional local bricks, it was observed that plastic sand bricks have low water absorption, low porosity and high compressive strength [5]. Dhote, 2016, conducted research on investigating the use of PET bottles as sustainable materials in construction. Tested the compressive strength of bottles filled with sand with a ratio between fly ash and different sand in each bottle, the results show that with a fly ash and sand ratio of 2: 1 the compressive strength results are $22,000 \mathrm{~kg}$, more greater than the ratio of $1: 2,1: 3,1: 1$, the smallest value in the material that contains sand is $7,260 \mathrm{~kg}$ [6]. The following research focuses on one of the eco-bricks technical properties, namely the compressive strength of the eco-bricks, when compared to the eco-bricks that have been made before, as well as with bricks, bricks and concrete bricks on the market.

\section{Material and Methods}

Research on eco-bricks is currently growing rapidly, there are several materials for making environmentally friendly bricks, from the simplest stages to the use of complex mixtures, the method of making eco-bricks can be divided into the following table (Table 1)

Table 1. Distribution of Eco-bricks Making Methods

\begin{tabular}{clccccc}
\hline \multirow{2}{*}{ Method } & \multicolumn{1}{c}{ Type } & $\begin{array}{c}\text { Warming } \\
\text { up }\end{array}$ & Compression & $\begin{array}{c}\text { Cement } \\
\text { binding }\end{array}$ & $\begin{array}{c}\text { Another } \\
\text { mixture }\end{array}$ & $\begin{array}{c}\text { Addition } \\
\text { of water }\end{array}$ \\
\cline { 2 - 7 } 1 & $\begin{array}{l}\text { Pure solid plastic } \\
2\end{array}$ & No & Yes & No & No & No \\
3 & $\begin{array}{l}\text { Solid plastic filler } \\
\text { Cold binding } \\
\text { plastic }\end{array}$ & No & Yes & No & Yes & No \\
4 & $\begin{array}{l}\text { Plastic hot binding } \\
\text { without water }\end{array}$ & Yes & Yes & Yes & Yes & Yes \\
5 & $\begin{array}{l}\text { Plastic hot binding } \\
\text { with water } \\
\begin{array}{l}\text { Cement plastic } \\
\text { binding }\end{array}\end{array}$ & Yes & Yes & Yes & Yes & No \\
\hline
\end{tabular}

Research on types of plastic fillers and cold plastic bindings, more developed in North Africa, Egypt, China and India by utilizing $20-40 \%$ of the plastic composition of the whole, while hot plastic binding is widely used in Central and South Africa, such as Nigeria, the heating method is carried out 
without the addition of cement, but the binding process of the material using plastic that is heated to form TAR.

The use of plastic bottles as eco-bricks is proven to be comfortably not much different from bricks from cement, even eco-bricks plastic bottles can reduce temperatures around $0.5-1^{\circ} \mathrm{C}$ in the home compared to the use of concrete bricks [7]. Thirugnanasambantha et al, examined the strength of plastic sand bricks method 6 , which is a mixture of ash, cement, sand and water, then mixed with plastic that has melted with a ratio of plastic and sand 1: $3,1: 4$ and 1: 5 , the results of compressive strength in sequence is $4.49\left(\mathrm{~N} / \mathrm{mm}^{2}\right) ; 5\left(\mathrm{~N} / \mathrm{mm}^{2}\right)$ and $5.6\left(\mathrm{~N} / \mathrm{mm}^{2}\right)$ [8]. Raj (2018), conducted a test of a mixture of plastic and quarry from $30 \%$ to $42 \%$, Ash $60 \%-40 \%$ and the remaining binding material in the form of cement (10 - 15\%), plastic material was crusher first, then mixed with ash and cement without using heating, in this case cement is used as a binding material, the results show a compressive strength of $1.85 \mathrm{~N} / \mathrm{mm}^{2}$ to $5.22 \mathrm{~N} / \mathrm{mm}^{2}$, the biggest yield is obtained with a plastic mixture of $37 \%$ [9]. Priya (2014), mixing ash, limestone, cement and plastic waste that has been crushed, adding $20 \%$ plastic and molding eco-bricks without heating, the result is the addition of plastic mixture can increase the compressive strength of eco-bricks, but did not mention the exact value [10].

Kamble (2017), examines eco-bricks method 2, which is without heating and without binding, only adding plastic and sand into plastic bottles and then compacted with a plastic mixture of $12 \%$ and the rest is sand, and the second eco-bricks is added by TAR, the result is eco-bricks has strength greater than just a mixture of cement and sand, the compressive stress value reaches $2.7 \mathrm{~N} / \mathrm{mm}^{2}$, while the addition of TAR is able to increase the compressive stress to $3 \mathrm{~N} / \mathrm{mm}^{2}$ [11].

Taaffe (2014) conducted an eco-bricks study using Method 1, which included inserting plastic waste into mineral water bottles, from 10 specimens with various types of densities, compressive strenght varied from $2.59 \mathrm{~N} / \mathrm{mm}^{2}$ to $2.8 \mathrm{~N} / \mathrm{mm}^{2}$, this variation is in line with the level of compaction of the plastic in the bottle, the denser the plastic in the bottle, the higher the value of compressive stress [12].

The method used in this study was a literature review with observations and test materials in the Pancasila University Concrete Laboratory. The field survey was conducted prior to the implementation of the socialization (Figure 1).
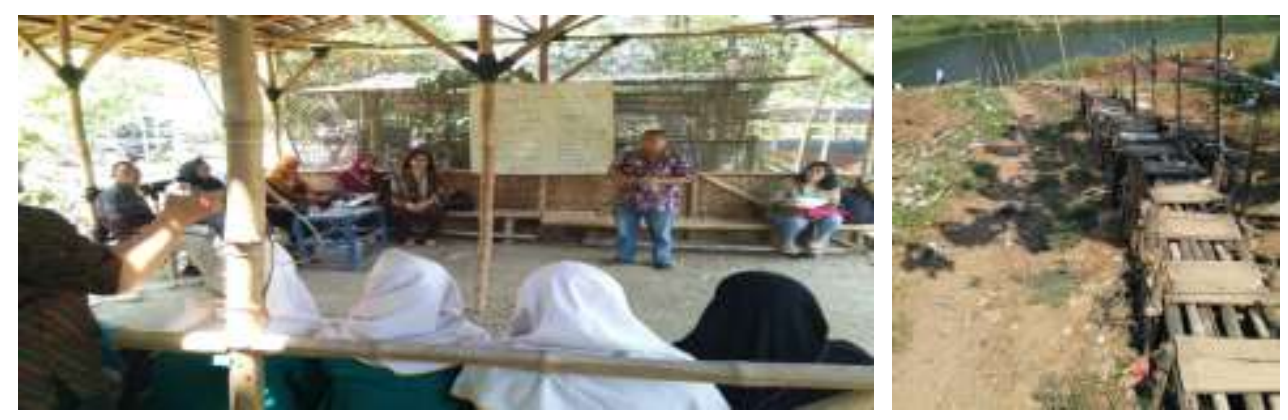

Figure 1. Survey of Citarum watershed conditions

Preparation the material for making eco-bricks, before testing. the materials for making eco-bricks are came from waste in the Citarum watershed, the waste that pollutes the Citarum River is mostly inorganic or non-biodegradable, for example plastic, bottles or glass for drinks, plastic food wrappers, and so on. As we all know, plastic waste is very difficult to decompose, it will take more than 100 years for plastic to decompose completely. Plastic waste is a source of environmental pollution in Indonesia. The benefits of using plastic products must be balanced with the calculation of the resulting negative impacts [13]. The properties of this plastic material make it difficult to replace it with other materials for various applications, especially in everyday life, from food packaging, household appliances, children's toys, electronics to automotive components. The increase in the use of plastic materials has resulted in an increase in the production of plastic waste from year to year [6]. The 
problem that occurs in the lower part of the Citarum River, especially in the Karawang district, there are no landfills at several points, so that people throw their garbage carelessly, including into rivers. The Ecovillage community consists of 15 RWs with approximately 20 members, which are active communities in collecting organic and inorganic waste in the community (Figure 2). However, the problem is the lack of knowledge from ecovillage members in recycling waste. One solution in this problem is by utilizing plastic waste that cannot be recycled as sustainable construction materials [14][15]. In making eco-bricks, before testing the materials are prepared to make eco-bricks with various predetermined variations. The steps to make an eco-bricks can be seen in Figure 3.

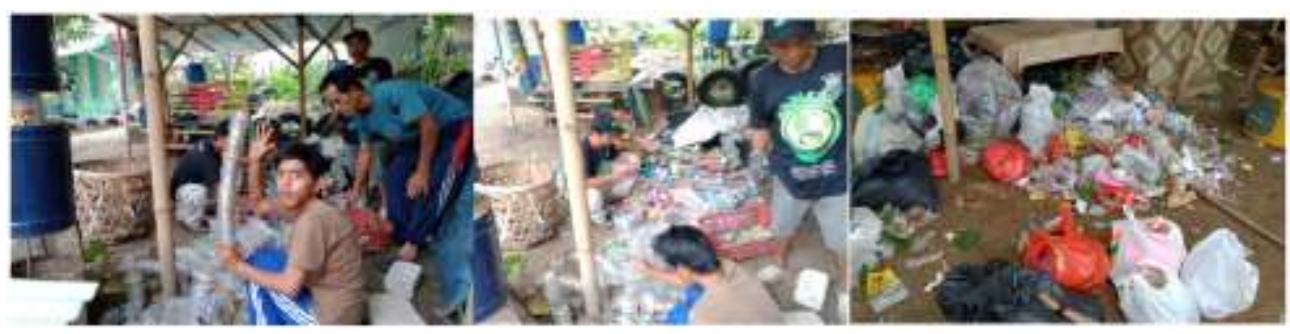

Figure 2. waste sorting process in the community

To start research on the first eco-bricks by conducting a literature review on the comparison of the results of the eco-bricks test object, it can be seen in table 1, after that making the test object, with consists of a plastic bottle with full plastic contents, a plastic bottle filled with sand, and a plastic bottle filled with plastic $20 \%$ and sand $80 \%$, which is tested on the compressive strength of each specimen and the results are compared with the compressive strength of materials on the market such as bricks and concrete.

After the specimen is ready to test comparison of 3 test specimens, each test object consisting plastic bottles with plastic filler (A), plastic bottle with sand + plastic filler (B), and plastic bottles with sand filler (C), (see Table 2).

Table 2. Eco-bricks Specimen

\begin{tabular}{clc}
\hline \multicolumn{1}{c}{ Specimen } & Quantity \\
\hline A & $\begin{array}{l}\text { Plastic Bottles (plastic } \\
\text { contents) }\end{array}$ & 1 \\
B & Plastic Bottles (plastic + sand) & 1 \\
C & Plastic Bottles (sand filled) & 1 \\
\hline
\end{tabular}

Eco-bricks research will conduct a compressive strength comparison of bricks (1) and concrete bricks (2), From each bricks and concrete bricks making consist of one test specimens (Table 3), then each weight is measured (Table 4).

Table 3. Eco-Bricks Comparative Specimen

\begin{tabular}{llc}
\hline \multicolumn{1}{c}{ Specimen } & Quantity \\
\hline 1. & Bricks & 1 \\
2. & Concrete Bricks & 1 \\
\hline
\end{tabular}

The steps for making an eco-brick (Figure 4), first Collect and separate plastic waste, prepare all kinds of plastic to make eco-bricks, second Choose the same orchid and bottle size, you should use the most bottles in your environment. Having an eco-brick in the same bottle makes it easy and embellishes the result, third Use a wooden stick to tamp down metal, glass, which will damage the bottle. Avoid 
paper and food scraps that will break down, and the last It is very important to ensure the quality of the eco-bricks made. Weigh eco-bricks that have been made, eco-bricks are good if they weigh at least $35 \%$ of the volume of the bottle. In a $1500 \mathrm{ml}$ bottle, the minimum weight is 500 grams, in a $600 \mathrm{ml}$ bottle, the minimum weight is 200 grams. In Table 4 is the weight of the eco-bricks made (Figure 5).

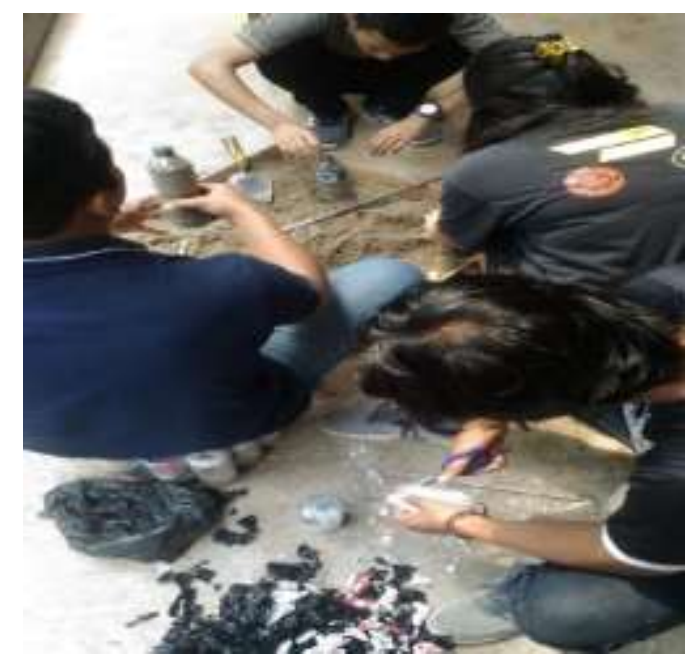

Figure 4. Making eco-bricks

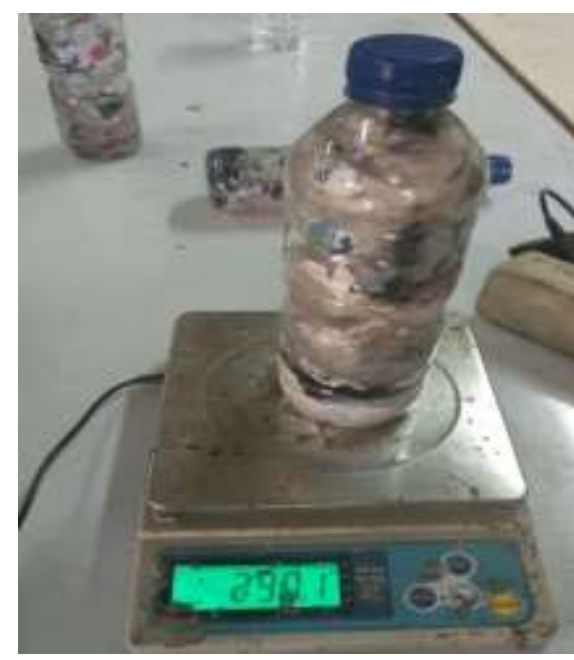

Figure 5. measuring Specimen weight

Table 4. Specimen weight

\begin{tabular}{clc}
\hline & \multicolumn{1}{c}{ Specimen } & $\begin{array}{c}\text { Specimen } \\
\text { weight (gram) }\end{array}$ \\
\hline A & Plastic Bottles (plastic contents) & 290,1 \\
B & Plastic Bottles (plastic + sand) & 855 \\
C & Plastic Bottles (sand filled) & 1.047 \\
\hline
\end{tabular}

\section{Result and Discussion}

The results of the compressive strength test on the Eco-bricks that have been made, when testing the position of the test object must be in a sleep state because for eco-bricks application in the field, the position used in the sleeping position is not the standing position [14].

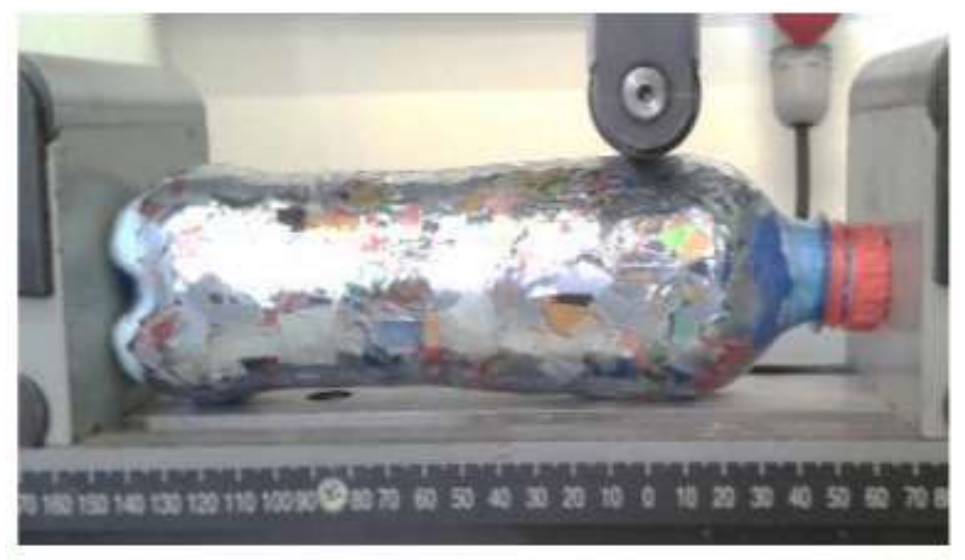

Figure 5. Position when performing the compressive strength test [13] 
The Eco-bricks that have been made is compressive strength test for each eco-brick variation, from the compressive strength test results will be displayed in the form of a bar chart, where the calculation to find the compressive strength is;

$$
\text { compressive strength }=\frac{\mathrm{P}}{\mathrm{A}}
$$

where:

$\mathrm{P} \quad=$ maximum load that will be given until a failure occurs $(\mathrm{N})$

$\mathrm{A}=\operatorname{area}\left(\mathrm{cm}^{2}\right)$

From the results of the eco-bricks test the compressive strength results obtained (Figure 6), for specimen in Table 2

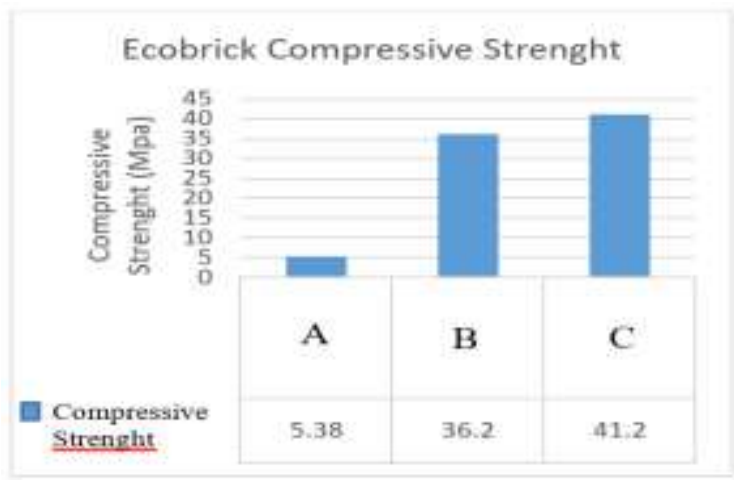

Figure 6. Eco-bricks Compressive Strength

The results of this research are used by University of Pancasila team to socialize how to make ecobricks and how strong the pressure on the eco-bricks material. Eco-bricks method is used to solve the problem of plastic waste along the Citarum river. This socialization was held in Tanjung Mekar Village, West Karawang District, Karawang Regency. The participants come from eco-village communities to reduce plastic waste that cannot be recycled.

From the results of tests that have been carried out on the compressive strength test, using the unit testing machine for the compressive strength test, it was see the strength of the eco-bricks when receiving a compressive load and to compare the compressive strength test against non-structural materials such as red bricks and concrete bricks and then the compressive strength test results from the eco-bricks were obtained. The highest compressive strength is $41.2 \mathrm{MPa}$ from plastic bottle sand filled material, compared to the results of the compressive strength of red bricks is $27 \mathrm{Mpa}$ and concrete bricks is $38 \mathrm{Mpa}$, the test can be respectively seen in Figure 7, for its specimen in Table (2) and (3).

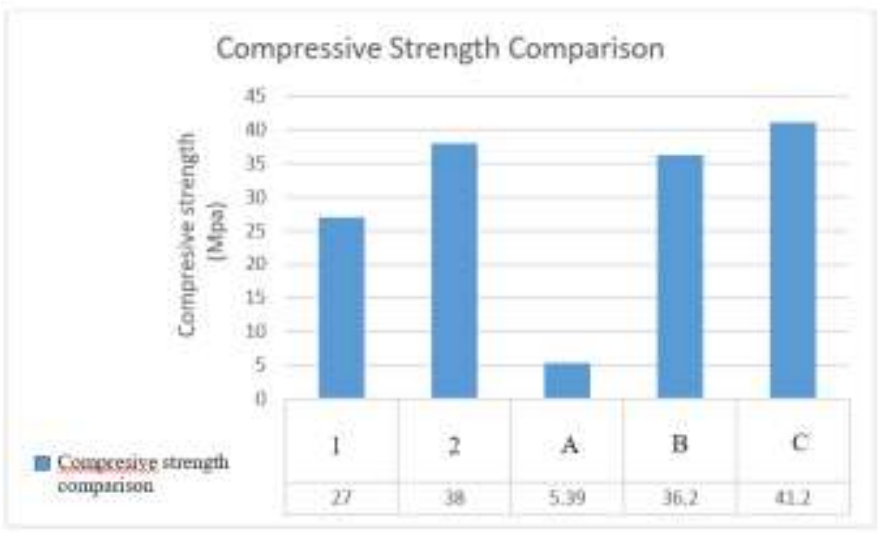

Figure 7. Eco-bricks Compressive Strength Comparison 
From the results of testing shows eco-bricks has a higher compressive strength when compared with red bricks and concrete bricks. After a strong test of the test specimen, a successful failure of each test object was seen, shown in Figure 8,9 and 10.

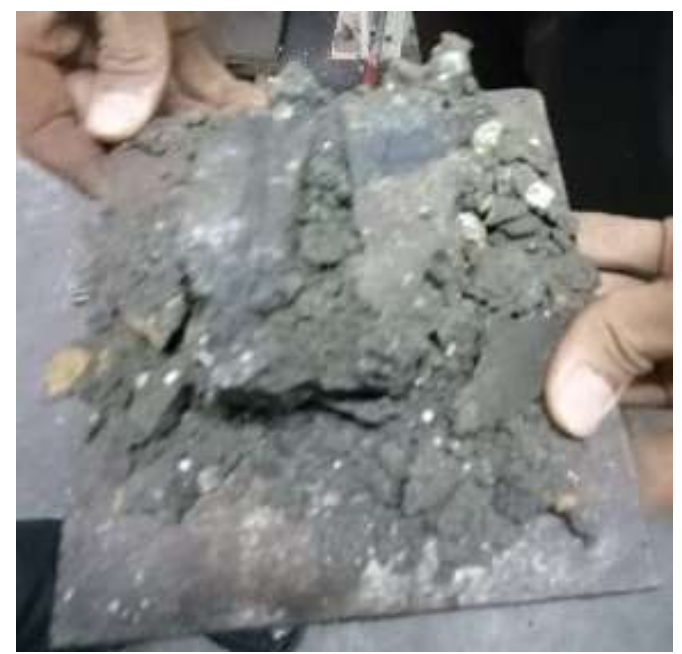

Figure 8. Concrete bricks after the test were destroyed

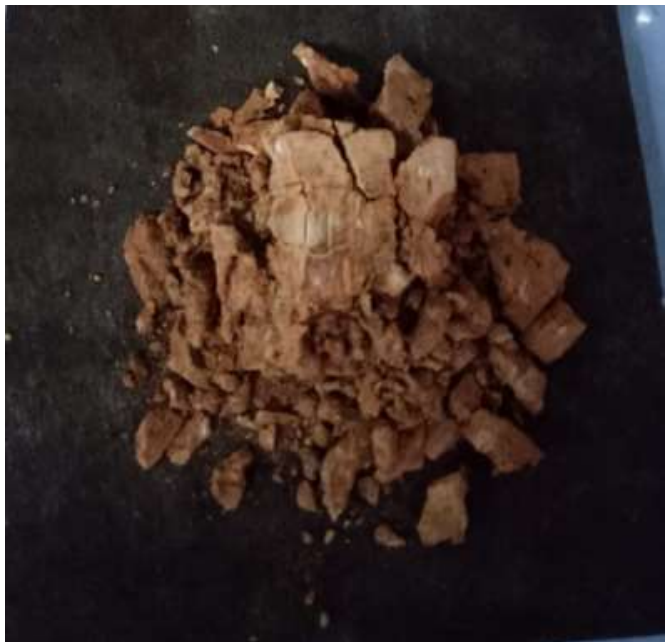

Figure 9. Red bricks after testing were destroyed

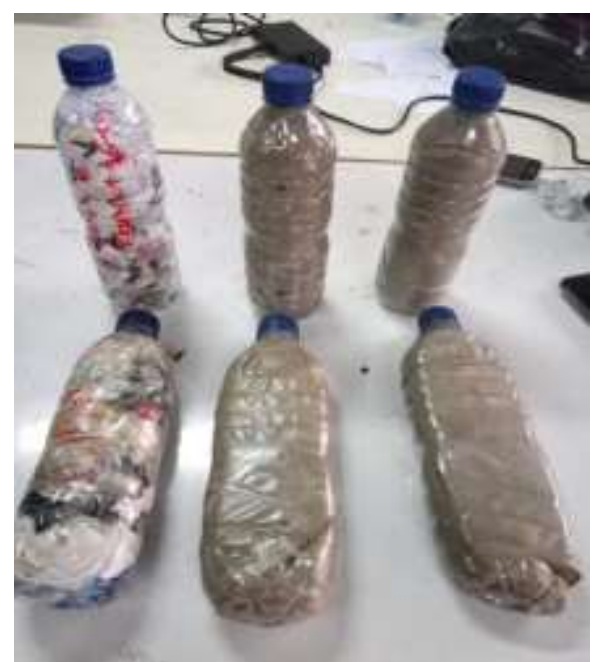

Figure 10. Eco-bricks after testing are not being destroyed

From Figure 8,9 and 10 shows that eco-bricks are stronger in accepting the burden when compared to other materials. If eco-bricks are applied to non-structural, eco-bricks is able to withstand greater load, in this case earthquake, because when an earthquake occurs structural/non-structural damage that is destroyed can injure humans.

\section{Conclusions}

Eco-bricks are the most effective solution to overcome the reduction of plastic waste that can damage the environment. From the compressive strength test results, eco-bricks which contains sand + plastic shows a higher result that is $41.2 \mathrm{MPa}$ when compared with red bricks that is $27 \mathrm{MPa}$ and the concrete bricks building is $38 \mathrm{MPa}$. Eco-bricks are able to receive a greater burden than the bricks and concrete bricks. Eco-bricks can be used as non-structural material. 


\section{Acknowledgements}

Thanks to who have contributed and supported the implementation of this research process, especially to the LPPM Faculty of Engineering, Pancasila University for the funds that have been given for this research

\section{References}

[1] R. Haribowo et al., "Behavior of toxicity in river basins dominated by residential areas," Contemp. Eng. Sci., vol. 10, no. 7, pp. 305-315, 2017, doi: 10.12988/ces.2017.7116.

[2] Gaelle Gourmelon, "Global Plastic Production Rises, Recycling Lags," 2015.

[3] World Economi Forum, "The New Plastics Economy Rethinking the future of plastics," 2016.

[4] Shuker, I.G., and S. . Cadman, "Marine debris," in Rapid Assesment, no. April, 2018, p. 46.

[5] L. B. Singh, "Manufacturing Bricks from Sand and Waste Plastics," Int. J. Eng. Technol. Manag. Appl. Sci. www.ijetmas.com, vol. 5, no. 3, pp. 426-428, 2017.

[6] S. U. Dhote, "Investigating the Use of PET Bottles as a Sustainable Material in Construction," Int. J. Res. Advent Technol., no. 2, pp. 13-16, 2016.

[7] M. Mokhtar et al., "Application of plastic bottle as a wall structure for green house," ARPN J. Eng. Appl. Sci., vol. X, no. X, pp. 1-5, 2015.

[8] N. Thirugnanasambantham, P. T. Kumar, R. Sujithra, R. Selvaraman, and P. Bharathi, "Manufacturing And Testing Of Plastic Sand Bricks," Int. J. Sci. Eng. Res. (IJOSER), vol. 5, no. 4, pp. 1-6, 2017.

[9] S. M. Raj, M. N. Gopal, T. P. Kumar, G. G. Prasath, and S. R. M. E, "An Experimental Study on the Strength \& Characteristics of Eco-Bricks from Garbage Dump," Int. J. Latest Technol. Eng. Manag. Appl. Sci., vol. VII, no. Iv, pp. 124-128, 2018.

[10] M. S. Priya and F. Ash, "Modern Technique in Fly Ash Bricks," Int. J. Math. Sci. Eng. (IJMSE), March 2014, vol. 3, no. 1, pp. 44-49, 2014.

[11] S. A. Kamble and D. M. Karad, "Plastic Bricks," Int. J. Adv. Res. Sci. Eng., vol. 06, no. 04, pp. 134-138, 2017.

[12] J. Taaffe, S. O. Sullivan, M. Ekhlasur, and V. Pakrashi, "Experimental characterisation of Polyethylene Terephthalate ( PET ) bottle Eco-bricks," J. Mater. Des., vol. 60, pp. 50-56, 2014, doi: 10.1016/j.matdes.2014.03.045.

[13] H. Chandra, Sunjonto, and Sarto, "Plastic Recyling In Indonesia By Converting Plastic Wastes ( Pet , Hdpe , Ldpe , And Pp ) Into Plastic Pellets," Plast. Recycl. Indones. by Convert. Plast. waste (PET, HDPE, LDPE PP) into Plast. Pellets, vol. 1, no. 1, pp. 65-72, 2015.

[14] F. C.Antico, G. Araya-Letelier, J. Wiener, and R. Gabriel, "Eco-bricks : A sustainable substitute for construction materials Eco-bricks : a sustainable substitute for construction materials Ecoladrillos: un reemplazo sustentable de materiales de construcción," Rev. la Constr., no. January 2018, 2017, doi: 10.7764/RDLC.16.3.518.

[15] M. V. Shoubi, M. V. Shoubi, and A. S. Barough, "Investigating the Application of Plastic Bottle as a Sustainable Material in the Building Construction," Int. J. Sci. Eng. Technol. Res., vol. 2, no. 1, pp. 28-34, 2013. 